\title{
B-cell subpopulations in humans and their differential susceptibility to depletion with anti-CD20 monoclonal antibodies
}

\author{
Maria J Leandro*
}

\begin{abstract}
In humans, different B-cell subpopulations can be distinguished in peripheral blood and other tissues on the basis of differential expression of various surface markers. These different subsets correspond to different stages of maturation, activation and differentiation. B-cell depletion therapy based on rituximab, an anti-CD20 mAb, is widely used in the treatment of various malignant and autoimmune diseases. Rituximab induces a very significant depletion of B-cell subpopulations in the peripheral blood usually for a period of 6 to 9 months after one cycle of therapy. Cells detected circulating during depletion are mainly CD20 negative plasmablasts. Data on depletion of CD20-expressing B cells in solid tissues are limited but show that depletion is significant but not complete, with bone marrow and spleen being more easily depleted than lymph nodes. Factors influencing depletion are thought to include not only the total drug dose administered and distribution into various tissues, but also B-cell intrinsic and microenvironment factors influencing recruitment of effector mechanisms and antigen and effector modulation. Available studies show that the degree of depletion varies between individuals, even if treated with the same dose, but that it tends to be consistent in the same individual. This suggests that individual factors are important in determining the final extent of depletion.
\end{abstract}

\section{Introduction to B-cell subpopulations}

In humans from birth all new B cells originate from common precursors in the bone marrow. In the bone marrow, peripheral blood and secondary lymphoid

*Correspondence: maria.leandro@ucl.ac.uk

Centre for Rheumatology and Bloomsbury Rheumatology Unit, Rayne Building, Room 416, University College London, 5 University Street, London WC1E 6JF, UK tissues, different B-cell subpopulations can be distinguished corresponding to different stages of maturation, activation and differentiation. B-cell subpopulations are characterised mainly by the differential expression of different cell surface markers that include various cluster of differentiation (CD) molecules and different surface immunoglobulin isotypes (B-cell antigen receptor). B-cell development can be separated into an earlier antigenindependent phase, which takes place in the bone marrow, and a later antigen-dependent phase that takes place mainly in secondary lymphoid tissues. In a simplified way, the different B-cell lineage subsets include pro-B cells, pre-B cells, immature and transitional $B$ cells, mature naïve $B$ cells, memory B cells, plasmablasts and plasma cells (Figure 1). Plasmablasts are recently differentiated antibody-producing cells that are usually shortlived but can recirculate and home to tissues such as the mucosa or the bone marrow, where they can differentiate into fully mature plasma cells. In addition, centroblasts and centrocytes are B cells participating in germinal centre reactions.

B-cell precursor subpopulations are found in the bone marrow. In the peripheral blood, transitional, naïve mature and memory B cells and plasmablasts, and more rarely plasma cells, can be identified. Plasma cells are more frequently seen in the bone marrow and peripheral lymphoid tissues. Centrocytes and centroblasts are found in secondary lymphoid tissues where germinal centre reactions take place, and are not found circulating in peripheral blood. Marginal zone B cells can be found in the marginal zone of the spleen and similar populations are described in particular locations in other secondary lymphoid tissues [1]. Marginal zone B cells in human adults are mainly memory B cells. There is still controversy on what drives formation of human marginal zone $B$ cells, to what extent they are similar to mice marginal zone $B$ cells and what is their relationship with circulating $\operatorname{IgM}^{+}$memory B-cell subsets $[1,2]$.

Immunophenotyping of $\mathrm{B}$ cells with multiparameter flow cytometry has allowed identification of an increasing number of different subpopulations, increasing our 


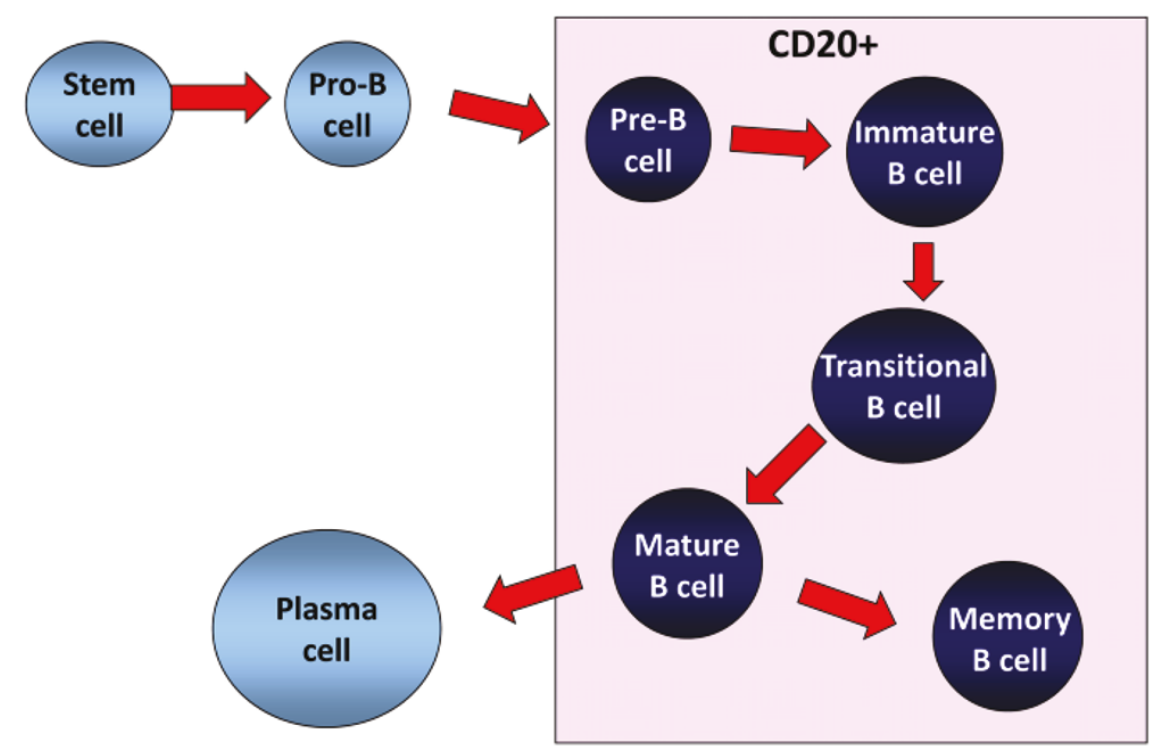

Figure 1. Simplified scheme of B-cell subpopulations in humans and CD20 expression.

knowledge of normal B-cell biology and, in particular, changes associated with different disease states. For example, different memory B-cell subsets have now been described in peripheral blood including subsets that do not express CD27, a marker previously thought to be present on all memory B cells [3,4]. Memory B-cell subpopulations include pre-switch $\operatorname{IgD}^{+} \operatorname{IgM}{ }^{+} \mathrm{CD} 27^{+}$ memory B cells, IgD-IgM+CD27 ${ }^{+}$memory B cells (IgMonly memory $\mathrm{B}$ cells), post-switch $\mathrm{IgA}^{+} \mathrm{CD} 27^{+}$and $\mathrm{IgG}^{+} \mathrm{CD} 27^{+}$memory B cells and also $\mathrm{IgA}^{+} \mathrm{CD} 27^{-}$and $\mathrm{IgG}^{+} \mathrm{CD} 27^{-}$memory $\mathrm{B}$ cells [5]. These memory subpopulations show different frequencies of somatic mutation and different replication histories that are thought to reflect their formation on primary or secondary germinal centres or outside germinal centre reactions [5]. A potential new marker for human memory B-cell subpopulations has been identified recently [6]. A proposal has been made that immunophenotyping of peripheral blood B cells should include the markers CD19, CD20, CD24, CD27, CD38 and IgD to be able to distinguish the major subpopulations [7]. More detailed information including separation into further subsets and subtle differences in activation status that may be important when looking at disease states may require use of other markers such as different immunoglobulin isotopes, activation markers or chemokine receptors [6,8-14].

\section{Anti-CD20 monoclonal antibodies - rituximab}

Anti-CD20 mAbs were developed in the late 1980s and in the 1990s for the treatment of non-Hodgkin's lymphoma of B-cell origin. Rituximab (MabThera ${ }^{\circ}$, Rituxan ${ }^{\circ}$; Roche, Basel, Switzerland) was licensed for the treatment of follicular lymphoma in 1997/98 and later for diffuse large non-Hodgkin's lymphoma and chronic lymphocytic leukaemia. In 2006 rituximab was licensed for the treatment of rheumatoid arthritis (RA). Rituximab is also used off-license for the treatment of other B-cell malignant diseases, in transplantation and for the treatment of a variety of other autoimmune diseases, predominantly diseases associated with the presence of autoantibodies. Various other therapeutic anti-CD20 mAbs are either available on the market (Ofatumumab - Arzerra ${ }^{\circ}$; GlaxoSmithKlein, UK - licensed for the treatment of chronic lymphocytic leukaemia), undergoing clinical trials or under development [15].

The CD20 antigen is expressed by the majority of cells in the B-lymphocyte lineage, but not by haematopoietic stem cells, the earliest B-cell precursors (pro-B cells) or terminally differentiated plasmablasts and plasma cells (Figure 1). The CD20 molecule is a transmembrane protein thought to function as a calcium channel and to be involved in B-cell activation and proliferation. A recent case report of a patient with CD20 deficiency suggested a role in T-cell-independent antibody responses [16].

Because haematopoietic stem cells are not directly depleted by anti-CD20 antibodies, one course of treatment with rituximab is followed by B-cell repopulation of the peripheral blood starting usually within 6 to 9 months - but it can take several months or even years for total B-cell numbers in the peripheral blood to recover to pretreatment levels. Repopulation occurs mainly with naïve B cells, with increased frequency and numbers of transitional B cells similar to that seen after 
bone marrow transplantation $[14,17]$. The time at which B-cell repopulation of the peripheral blood starts is probably determined by the extent of earlier depletion, drug clearance and the capacity of the bone marrow to regenerate. Variability in time to repopulation in primate animal models did not seem to be dose dependent [18]. Factors influencing B-cell precursor formation in humans are poorly understood, as are factors that determine to what extent a fully functional B-cell repertoire is regenerated and how long it takes. Whether age or other individual characteristics influence repopulation is not known $[19,20]$.

The fact that plasma cells are also not directly depleted by anti-CD20 antibodies explains why, in the majority of patients, serum total immunoglobulin levels remain within the normal range after treatment with one course of rituximab. Several studies have shown that serum levels of several autoantibodies decrease after treatment with rituximab (although they do not usually become undetectable) and do so proportionally more than total immunoglobulin levels or anti-microbial antibodies [21-23]. This observation suggests that these autoantibodies are produced by proportionally more shortlived plasma cells and therefore are more dependent on the formation of new plasma cells, which is interrupted by B-cell depletion [23].

Treatment with rituximab is associated with major depletion of normal B cells in vivo. Depletion in the peripheral blood is frequently higher than $99 \%$ but depletion in other tissues has been less well studied, with several studies documenting that depletion in solid tissues with rituximab is frequently not complete and can show considerable variation between individuals. In vitro, rituximab depletes malignant $B$ cells by antibody-dependent cellular cytotoxicity, complement-mediated cytotoxicity and induction of apoptosis. In vivo, rituximab is thought to act mainly by inducing antibody-dependent cellular cytotoxicity with activation of complement also contributing [24]. One of the consistent findings in several of the animal and earlier human studies is the variability of depletion seen with anti-CD20 mAbs in different individuals even when treated with the same dose $[18,25,26]$. Interestingly, depletion in the same individual tends to be consistent in different tissues, suggesting that individual characteristics are important.

\section{Resistance to depletion with anti-CD20 monoclonal antibodies}

Because depletion is achieved by binding of the mAbs to the cell surface CD20 molecules, the final extent of depletion will necessarily depend on the relationship between total number of $\mathrm{B}$ cells and total dose of rituximab administered, on accessibility of the drug and effector immune cells to the tissues where B cells are located, on intrinsic or extrinsic factors that may influence B-cell survival and on the efficacy of recruited host immune mechanisms responsible for depletion.

Former small dose-ranging studies in lymphoma and in animal models have shown that B cells in the peripheral blood are readily killed by anti-CD20 antibodies but that higher doses and higher serum levels are needed for depletion in extravascular sites $[18,24,25]$.

Factors influencing antigen and effector modulation are thought to be important in determining the final extent of depletion achieved (Table 1) [18,27,28]. Antigen modulation refers to antigen endocytosis/modulation after binding to the antibody. Contrary to what was originally thought, this can be seen with the CD20 molecule after binding with certain anti-CD20 antibodies including rituximab [29]. This can lead to less recruitment of Fcy receptors on effector immune cells and to decreased serum drug levels. Effector modulation refers to genetic and acquired mechanisms that can enhance or diminish effector immune cell function and therefore influence the extent of depletion. For example, a Fcy receptor IIIa polymorphism that can influence affinity for IgG has been associated with clinical response in lymphoma [28]. Profound complement depletion as seen during treatment of chronic lymphocytic leukaemia with rituximab can be a limiting factor for further depletion [28].

Intrinsic B-cell factors that may influence depletion include high expression of complement regulatory proteins as seen in chronic lymphocytic leukaemia [28]. In cynomolgus monkeys, different sensitivities to rituximab were associated with, but not fully explained by, different levels of expression of CD20 [30]. Binding of rituximab to CD20 leads to translocation of the CD20 molecule to lipid rafts. Alterations in lipid raft composition and treatment with statins have been associated with less good responses to rituximab [28]. To what extent external B-cell survival factors, in particular the cytokine B-cell activating factor (BAFF), influence depletion is not known, although it has been suggested that local high levels of BAFF may contribute to resistance to depletion by rituximab [31].

In animal models, certain subpopulations have been shown to be more resistant to depletion with anti-CD20 antibodies but this varies with the mice strain used and whether they were studies using human CD20 transgenic mice treated with anti-human CD20 mAbs or nontransgenic mice treated with anti-mouse CD20 mAbs $[32,33]$. Populations that were found to be more resistant to depletion were peritoneal B1-type B cells, germinal centre B cells and marginal zone B cells $[32,33]$. Insufficient depletion of peritoneal B1 cells is thought to be due to the lack of effector cells in the peritoneal space [33]. Differential sensitivity of germinal centre and marginal 


\begin{tabular}{l}
$\begin{array}{l}\text { Table 1. Potential mechanisms of resistance or of } \\
\text { susceptibility to depletion by anti-CD20 monoclonal } \\
\text { antibodies }\end{array}$ \\
\begin{tabular}{ll}
\hline Depletion & Mechanisms \\
\hline B-cell and antigen related & Lack of CD20 surface expression \\
& CD20 (antigen) modulation/endocytosis \\
& Lipid raft composition \\
& Expression of complement regulatory \\
proteins
\end{tabular} \\
$\begin{array}{ll}\text { Immune host phenomena related } & \text { FcyRlllA polymorphisms } \\
& \text { FcyRIIB expression } \\
& \text { C1q polymorphisms } \\
& \text { Exhaustion of cytotoxic mechanisms } \\
\text { (for example, complement) }\end{array}$ \\
\hline
\end{tabular}

Mechanisms reviewed in $[24,28]$.

zone $\mathrm{B}$ cells to anti-CD20 antibodies has also been described in cynomologous monkeys, with differences appearing more prominent in the lymph nodes than in the spleen [30]. The relative resistance of some populations is thought to be related to B-cell and microenvironment differences responsible for antigen or effector modulation or related to direct resistance of the $B$ cells involved. In an autoimmune mouse model of lupus, B cells were more resistant to depletion when compared with nonautoimmune mice and more frequent administration of larger doses increased efficacy of depletion [34]. Less good depletion has also been associated with acquired defects in antibody-dependent cellular cytotoxicity in the same autoimmune mouse model of lupus [35].

To what extent the differential susceptibility of various B-cell subsets demonstrated in some of the animal models reflects what happens in humans in vivo is not known. Different B-cell malignancies deriving from B cells at different stages of differentiation and different tumour locations are also associated with differential responses to treatment with anti-CD20 mAbs but susceptibility of the correspondent normal human B-cell subpopulations is expected to be substantially different. Whether there are any differences in susceptibility to depletion of autoreactive human B-cell clones when compared with nonautoreactive ones, as suggested by mouse models [34], and whether there are any significant differences in susceptibility to depletion of disease-associated B-cell clones between different autoimmune diseases are also not known.

In addition, administration of chimaeric anti-CD20 mAbs such as rituximab can be associated with formation of human anti-chimaeric antibodies that can influence drug action and clearance. Although most large studies show no association between the presence of human anti-chimaeric antibodies and clinical response or depletion, this association has been described, for example, in small studies in systemic lupus erythematosus patients [36,37].

With evidence showing that not all B cells that bind rituximab are depleted there is an interest in knowing what exactly happens to these cells in vivo during the period of depletion. Are they eventually depleted later on, particularly if they recirculate in peripheral blood? Are they functionally impaired? Are they able to expand in an environment with less competition and raised BAFF levels? Kamburova and colleagues tried to address some of these issues by studying the in vitro effects of incubation with rituximab on proliferation, activation and differentiation of nondepleted human normal peripheral blood B cells [38]. They reported that incubation with rituximab (for 30 minutes at $5 \mu \mathrm{l} / \mathrm{ml}$ ) inhibited the proliferation of stimulated $\mathrm{CD}^{-} 7^{-}$naïve $\mathrm{B}$ cells but not of $\mathrm{CD} 27^{+}$memory $\mathrm{B}$ cells and this was associated with a relative increase of $B$ cells with an activated naïve phenotype. $B$ cells stimulated in the presence of rituximab induced stronger T-cell proliferation and the T-cell population showed a more Th2-like phenotype. These results suggest that B cells which are exposed to rituximab but are not depleted may have altered function and that naïve and memory B cell populations may be differentially affected. Whether any of these phenomena occur in vivo and what their implications would be are unclear. Interestingly, and similar to what happens after bone marrow transplantation, the residual $\mathrm{B}$ cells are not able to expand and repopulate the peripheral blood, even in the presence of abundant BAFF.

\section{B-cell depletion in peripheral blood}

Administration of rituximab is usually associated with a rapid and profound depletion of circulating $B$ cells in the peripheral blood [18]. Major depletion effector cells are probably macrophages from the reticulo-endothelial system [24]. Studies in autoimmune diseases - in particular, RA and systemic lupus erythematosus - have documented variable degrees and durations of B-cell depletion in peripheral blood in different individuals following treatment with rituximab with standard doses $[17,36,37$, 39-41]. Incomplete B-cell depletion in the peripheral blood, as defined by B-cell counts $>5$ cells $/ \mu$ l after treatment with rituximab, has been well documented in cases of patients with autoimmune diseases, more frequently in systemic lupus erythematosus than in RA $[17,36,37]$. Persistent presence of circulating B cells has also been documented with high-sensitivity flow cytometry and has been associated with no or less good response to treatment $[39,40]$. Insufficient depletion can be seen on retreatment with documented very rapid clearance of rituximab in association with a marked human antichimaeric antibody response [42]. Other mechanisms 
underlying incomplete depletion in the peripheral blood have not been well studied but are probably a consequence of more rapid clearance of the drug and/or antigen and effector modulation phenomena [17,24,36,37].

The very small numbers of circulating $B$ cells that can be detected during periods of depletion usually show a phenotype of plasmablasts but cells with memory or even naïve $B$ cells have also been reported $[17,40,41,43]$. The CD20 antigen cannot usually be detected in these memory B cells, suggesting that it is masked by binding to rituximab because the drug can be detected in the circulation for several months [26]. Mei and colleagues described that, similarly to their controls, the majority of circulating plasmablasts/plasma cells detected during depletion were positive for IgA and a reasonable proportion expressed markers suggesting they had been formed in mucosal tissue and were circulating back to mucosal areas [44]. These results suggest that depletion in mucosal-associated lymphoid tissue may be particularly less pronounced.

Repopulation of the peripheral blood after treatment with a standard dose of rituximab usually starts 6 to 9 months after treatment with predominantly transitional and naïve $\mathrm{B}$ cells as previously mentioned. Frequently, repopulation with larger numbers of memory B cells and/ or plasmablasts has been associated with earlier relapse $[17,40,45]$. At repopulation, the decrease from baseline in the frequency of pre-switch memory B cells $\left(\mathrm{CD} 27^{+} \mathrm{IgD}{ }^{+}\right)$ was larger than the decrease in the switched memory B-cell population $\left(\mathrm{CD}^{2} 7^{+} \mathrm{IgD}-\right)$ [46]. However, to what extent circulating memory $\mathrm{B}$ cells at repopulation are old memory $B$ cells that have not been depleted by rituximab or recently differentiated memory B cells is not known. We therefore do not know whether relative frequencies of the different B-cell subpopulations at repopulation can tell us anything about the subpopulations of cells that may have resisted depletion.

In RA, nonresponse has been associated with higher numbers of plasmablasts before treatment and early relapse has been associated with higher numbers of CD27 ${ }^{+}$memory B cells before treatment $[39,45]$. Again, to what extent this may indicate less susceptibility and insufficient depletion of memory B-cell subsets in association with no response or with a shorter response is not known.

\section{B-cell depletion in bone marrow and secondary lymphoid tissues}

Unfortunately, there are limited data on the degree of depletion of normal B cells in secondary lymphoid organs and other solid tissues in human individuals treated with rituximab, and hardly any data on differential susceptibility to depletion of different subpopulations in different tissues except for the expected resistance of
CD20- plasmablasts and plasma cells to depletion [47]. Animal studies in primates showed that increasingly higher doses are needed to deplete bone marrow, spleen and lymph nodes in this order $[18,48,49]$. These studies also showed that B-cell depletion in solid tissues was frequently significant, but not complete, and that it varied from site to site and from individual to individual even when the same doses were used. Interestingly, consistency regarding the degree of depletion achieved in different lymph nodes in the same individual was described $[18,20,48,49]$. As previously mentioned, mice studies suggested that B cells resident in tissues other than peripheral blood may be partly resistant to depletion by anti-CD20 antibodies either because of local defective effector mechanisms or because the $\mathrm{B}$ cells have a particular phenotype that renders them resistant to depletion in association with their specific state of maturation, activation or differentiation.

In bone marrow samples of RA patients treated with rituximab a relatively high number of B-cell precursors subpopulations can be seen [50-52]. This has been documented at 1 month or 3 to 4 months after treatment, at a time when peripheral blood repopulation had not yet started [50,51]. Persistence of CD20- plasma cells has been observed as expected [50,51]. In the two studies where phenotyping was more detailed, the cells found were mainly B-cell precursors and recirculating memory $\mathrm{B}$ cells [50,52]. Once again, variability between individuals was observed [50,52].

The presence of cells of B-cell lineage that presumably should be expressing CD20 has therefore been well documented and rituximab is probably still present and binds to the CD20 molecule, preventing its detection in flow cytometry as discussed above [50,51]. Alternatively, antigen endocytosis/modulation could occur. Whether the developing $\mathrm{B}$ cells are eventually depleted by antiCD20 recruited mechanisms or whether their full maturation is prevented by binding of rituximab to CD20 is not known.

In a study of autopsy samples of lymph node and spleen of patients with lymphoma treated with rituximab monotherapy or with rituximab and chemotherapy, a substantial reduction of B-cell populations was documented - with only three out of eight patients showing any reactivity for markers of cells of B-cell lineage in the lymph nodes and only one out of eight in the spleen by immunohistochemistry [53]. Similarly, a study in patients with idiopathic thrombocytopenic purpura showed major and prolonged depletion of B cells in the spleen of 10 patients treated with rituximab [54]. The number of residual B cells correlated with time from rituximab treatment but was $<5 \%$ of spleen lymphocytes in eight out of nine patients studied up to 10 months after rituximab treatment. Plasma cells were detected at 
increased frequencies when compared with patients with idiopathic thrombocytopenic purpura not treated with rituximab. In a patient with idiopathic thrombocytopenic purpura, analysis of spleen and bone marrow samples by flow cytometry revealed complete depletion of B cells 3 months after treatment with rituximab [55]. In another patient with idiopathic thrombocytopenic purpura, B cells in the spleen 3 months after rituximab treatment were only present in very low numbers (around $0.1 \%$ ) [56]. Interestingly, in this later study persistence of memory B cells against vaccinia virus in the spleen of patients previously treated with rituximab was documented [56]. In kidney transplant patients that had a splenectomy 3 to 12 days after treatment with rituximab, naïve $B$ cells were reduced but not memory $B$ cells or plasma cells [57].

Vaccination studies in patients treated with rituximab can provide indirect data on B-cell subpopulations that may be resistant to depletion with anti-CD20 mAbs. However, published data are difficult to interpret because of the small number of patients, effects of concomitant therapy and the background disease itself on the humoral response to vaccines and, in particular, because studies included patients at various stages of B-cell depletion or repopulation at the time of vaccination. Most studies have looked at responses to influenza vaccines and showed absent or decreased humoral responses to vaccination in patients previously treated with rituximab when compared with normal controls or patients not treated with rituximab [58-64]. Some studies described a positive relationship between the antibody responses to vaccination and number of circulating $B$ cells at the time of vaccination [64] or the time from last rituximab treatment $[60,62]$. Interestingly, when circulating influenzaspecific B cells were studied 6 days after vaccination, specific IgM-B cells were decreased in patients treated with rituximab 6 months previously when compared with controls but IgA B cells and IgG B cells were similar [61]. In a study in lymphoma patients, responses to recall antigens in the influenza vaccine were also seen but not to the new antigen [65]. These studies suggest that memory $B$ cells are more resistant to depletion than naïve $B$ cells and can survive treatment with rituximab and be recruited in a secondary immune response.

\section{B-cell depletion in other solid tissues}

In patients with RA, several studies have documented significant but variable depletion of B cells in samples of synovial tissue of involved joints and persistence of CD20- plasma cells [66-68]. Variability in depletion between individuals was not explained by differences in rituximab serum levels [69]. In a study in patients with Sjogren's syndrome, repeated salivary gland biopsies 3 months after treatment with rituximab showed incomplete depletion of B cells [70]. A previous study had shown complete depletion at 4 months [71]. In a study of renal explanted grafts in two patients treated with one dose (4 months earlier) or two doses (10 months earlier) of rituximab, despite depletion of peripheral blood, tertiary lymphoid structures containing B cells were seen [72].

\section{Conclusion}

In summary, although there are several studies looking at the degree and duration of B-cell depletion induced by rituximab in the peripheral blood, there is very little information on the exact degree of depletion in solid tissues - and, in particular, few definite data on whether different subtypes of CD20-expressing B cells are more or less susceptible to depletion by anti-CD20 antibodies. The data available suggest that there is variability between individuals on the extent and duration of depletion induced and that this may have clinical correlations with response and duration of response in autoimmune diseases. Understanding what underlies this variability and, in particular, whether drug clearance and antigen and effector modulation phenomena are involved - has the potential to lead to more effective B-cell depleting strategies and to increasing our understanding of the role that different B-cell subtypes play in the pathogenesis of the different autoimmune diseases.

\section{Abbreviations}

BAFF, B-cell activating factor; CD, cluster of differentiation; mAb, monoclonal antibody; RA, rheumatoid arthritis; Th, T-helper type.

\section{Competing interests}

The author has received consultancy fees and funding to attend international medical meetings from Roche Pharmaceuticals and consultancy fees and research funding from GlaxoSmithKlein.

\section{Declarations}

This article has been published as part of Arthritis Research \& Therapy Volume 15 Supplement 1, 2013: B cells in autoimmune diseases: Part 2. The supplement was proposed by the journal and content was developed in consultation with the Editors-in-Chief. Articles have been independently prepared by the authors and have undergone the journal's standard peer review process. Publication of the supplement was supported by Medimmune.

\section{Published: 25 March 2013}

\section{References}

1. Weill JC, Weller S, Reynaud CA: Human marginal zone B cells. Annu Rev Immunol 2009, 27:267-285.

2. Lammers AJJ, de Porto APNA, Bennink RJ, van Leeuwen EM, Biemond BJ, Goslings JC, van Marle J, ten Berge IJ, Speelman P, Hoekstra JB: Hyposplenism: comparison of different methods for determining splenic function. Am J Hematol 2012, 87:484-489.

3. Klein U, Rajewsky K, Kuppers R: Human immunoglobulin (Ig) $\mathrm{M}^{+} \lg \mathrm{D}^{+}$ peripheral blood B cells expressing the CD27 cell surface antigen carry somatically mutated variable region genes: $C D 27$ as a general marker for somatically mutated (memory) B cells. J Exp Med 1998, 188:1679-1689.

4. Fecteau JF, Cote G, Neron S: A new memory CD27-lg $\mathrm{G}^{+} \mathrm{B}$ cell population in peripheral blood expressing $\mathrm{VH}$ genes with low frequency of somatic mutation. J Immunol 2006, 177:3728-3736. 
5. Berkowska MA, Driessen GJA, Bikos V, Grosserichter-Wagener C, Stamatopoulos K, Cerutti A, He B, Biermann K, Lange JF, van der Burg M, van Dongen JJ, van Zelm MC: Human memory B cells originate from three distinct germinal center-dependent and -independent maturation pathways. Blood 2011, 118:2150-2158.

6. Koethe S, Zander L, Koster S, Annan A, Ebenfelt A, Spencer J, Bemark M: Pivotal advance: CD45RB glycosylation is specifically regulated during human peripheral B cell differentiation. J Leukoc Biol 2011, 90:5-19.

7. Maecker HT, McCoy JP, Nussenblatt R: Standardizing immunophenotyping for the Human Immunology Project. Nat Rev Immunol 2012, 12:191-200.

8. Bohnhorst JO, Bjorgan MB, Thoen JE, Natvig JB, Thompson KM: Bm1-Bm5 classification of peripheral blood $B$ cells reveals circulating germinal centre founder cells in healthy individuals and disturbance in the B cell subpopulations in patients with primary Sjogren's syndrome. J Immunol 2001, 167:3610-3618.

9. Sims GP, Ettinger R, Shirota Y, Yarboro CH, Illei GG, Lipsky PE: Identification and characterization of circulating human transitional B cells. Blood 2005 105:4390-4398.

10. Palanichamy A, Barnard J, Zheng B, Owen T, Quach T, Wei C, Looney RJ, Sanz I, Anolik JH: Novel human transitional B cell populations revealed by B cell depletion therapy. J Immunol 2009, 182:5982-5993.

11. Lee J, Kuchen S, Fischer R, Chang S, Lipsky PE: Identification and characterization of a human $\mathrm{CD}^{+}$pre-naïve $\mathrm{B}$ cell population. I Immunol 2009, 182:4116-4126.

12. Suryani S, Fulcher DA, Santner-Nanan B, Nanan R, Wong M, Shaw PJ, Gibson J, Williams A, Tangye SG: Differential expression of CD21 identifies developmentally and functionally distinct subsets of human transitional $B$ cells. Blood 2010, 115:519-529.

13. Wei C, Jung J, Sanz I: OMIP-003: phenotypic analysis of human memory B cells. Cytometry A 2011, 79:894-896.

14 Bemark M. Holmqvist J, Abrahamsson J, Mellgren K. Translational minireview series on $B$ cell subsets in disease. Reconstitution after haematopoietic stem cell transplantation - revelation of B cell developmental pathways and lineage phenotypes. Clin Exp Immunol 2011, 167:15-25.

15. Alduaji $W$, Illidge TM: The future of anti-CD20 monoclonal antibodies: are we making progress? Blood 2011, 117:2993-3001.

16. Kuijpers TW, Bende RJ, Baars PA, Grummels A, Derks IA, Dolman KM Beaumont T, Tedder TF, van Noesel CJ, Eldering E, van Lier RA: CD20 deficiency in humans results in impaired T cell-independent antibody responses. J Clin Investig 2010, 120:214-222.

17. Leandro MJ, Cambridge G, Ehrenstein M, Edwards JC: Reconstitution of peripheral blood $B$ cells after depletion with rituximab in patients with rheumatoid arthritis. Arthritis Rheum 2006, 54:613-620.

18. Reff ME, Carner K, Chambers KS, Chinn PC, Leonard JE, Raab R, Newman RA, Hanna N, Anderson DR: Depletion of B cells in vivo by a chimeric mouse human monoclonal antibody to CD20. Blood 1994, 83:435-445.

19. Bulati M, Buffa S, Candore G, Caruso C, Dunn-Walters DK, Pellicano M, Wu YC, Colonna Romano G: B cells and immunosenescence: a focus on lgG $\mathrm{G}^{+} \mathrm{lgD}$ CD27- B cells in aged humans. Ageing Res Rev 2011, 10:274-284.

20. Keren Z, Naor S, Nussbaum S, Golan K, Itkin T, Sasaki Y, Scmidt-Supprian M, Lapidot T, Melamed D: B-cell depletion reactivates B lymphopoiesis in the $B M$ and rejuvenates the $B$ lineage in aging. Blood 2011, 117:3104-3112.

21. Cambridge G, Leandro MJ, Edwards JC, Ehrenstein MR, Salden M, BodmanSmith M, Webster AD: Serologic changes following B lymphocyte depletion therapy for rheumatoid arthritis. Arthritis Rheum 2003, 48:2146-2154

22. Cambridge G, Isenberg DA, Edwards JC, Leandro MJ, Migone TS, Teodorescu $M, S t o h l W: B$ cell depletion therapy in systemic lupus erythematosus: relationships among serum B lymphocyte stimulator levels, autoantibody profile and clinical response. Ann Rheum Dis 2008, 67:1011-1016.

23. Teng YKO, Wheater G, Hogan VE, Stocks P, Levarht EWN, Huizinag TWJ, Toes REM, van Laar JM: Induction of long-term B-cell depletion in refractory rheumatoid arthritis patients preferentially afftects autoreactive more than protective humoral immunity. Arthritis Res Ther 2012, 14:R57.

24. Stevenson FK, Stevenson GT: Follicular lymphoma and the immune system: from pathogenesis to antibody therapy. Blood 2012, 119:3659-3667.

25. Press OW, Appelbaum F, Ledbetter JA, Martin PJ, Zarling J, Kidd P, Thomas ED: Monoclonal antibody 1 F5 (anti-CD20) serotherapy of human B cell lymphomas. Blood 1987, 69:584-591.

26. Maloney DG, Liles TM, Czerwinski DK, Waldichuk C, Rosenberg J, Grillo-Lopez, Levy R: Phase I clinical trial using escalating single-dose infusion of chimeric anti-CD20 monoclonal antibody (IDEC-C2B8) in patients with recurrent B-cell lymphoma. Blood 1994, 84:2457-2466.

27. Beurskens FJ, Lindorfer MA, Farooqui M, Beum PV, Engelberts P, Mackus WJ, Parren PW, Wiestner A, Taylor RP: Exhaustion of cytotoxic effector systems may limit monoclonal antibody-based immunotherapy in cancer patients. J Immunol 2012, 188:3532-3541

28. Rezvani AR, Maloney DG: Rituximab resistance. Best Pract Res Clin Haematol 2011, 24:203-216

29. Beers SA, French RR, Chan HTC, Lim SH, Jarrett TC, Vidal RM, Wijayaweera SS, Dixon SV, Kim H, Cox KL, Kerr JP, Johnston DA, Johnson PW, Verbeek JS, Glennie MJ, Cragg MS: Antigenic modulation limits the efficacy of antiCD20 antibodies: implications for antibody selection. Blood 2011, 115:5191-5210.

30. Vugmeyster Y, Howell K, McKeever K, Combs D, Canova-Davis E: Differential in vivo effects of rituximab on two B-cell subsets in cynomolgus monkeys. Int Immunopharmacol 2003, 3:1477-1481.

31. Quartuccio L, Fabris M, Moretti M, Barone F, Bombardieri M, Rupolo M, Lombardi S, Pitzalis C, Beltrami CA, Curcio F, De Vita S: Resistance to rituximab therapy and local BAFF overexpression in Sjogren's syndromerelated myoepithelial sialadenitis and low-grade parotid B-cell lymphoma. Open Rheumatol J 2008, 2:38-43.

32. Gong Q, Ou Q, Ye S, Lee WP, Cornelius J, Diehl L, Lin WY, Hu Z, Lu Y, Chen Y, Wu Y, Meng YG, Gribling P, Lin Z, Nguyen K, Tran T, Zhang Y, Rosen H, Martin F, Chan AC: Importance of cellular microenvironment and circulatory dynamics in B cell immunotherapy. J Immuno/ 2005, 174:817-826.

33. Hamaguchi Y, Uchida J, Cain DW, Venturi GM, Poe JC, Haas KM, Tedder TF: The peritoneal cavity provides a protective niche for $\mathrm{B} 1$ and conventional $\mathrm{B}$ lymphocytes during anti-CD20 immunotherapy in mice. J Immuno/ 2005, 174:4389-4399.

34. Ahuja A, Shupe J, Dunn R, Kashgarian M, Kehry MR, Shlomchik MJ: Depletion of B cells in murine lupus: efficacy and resistance. J Immunol 2007, 179:3351-3361.

35. Ahuja A, Teichmann LL, Wang H, Dunn R, Kehry MR, Shlomchik MJ: An acquired defect in IgG-dependent phagocytosis explains the impairment in antibody-mediated cellular depletion in lupus. J Immunol 2011 187:3888-3894.

36. Looney RJ, Anolik JH, Campbell D, Felgar RE, Young F, Arend LJ, Sloand JA, Rosenblatt J, Sanz I: B cell depletion as a novel treatment for systemic lupus erythematosus: a phase I/II dose-escalation trial of rituximab. Arthritis Rheum 2004, 50:2580-2589.

37. Albert D, Dunham J, Khan S, Stansberry J, Kolasinski S, Tsai D, Pullman-Mooar S, Barnack F, Striebich C, Looney RJ, Prak ET, Kimberly R, Zhang Y, Eisenberg R: Variability in the biological response to anti-CD20 B cell depletion in systemic lupus erythematosus. Ann Rheum Dis 2008, 67:1724-1731.

38. Kamburova EG, Koenen HJPM, Boon L, Hilbrands LB, Joosten I: In vitro effects of rituximab on the proliferation, activation and differentiation of human B cells. Am J Transplant 2012, 12:341-350.

39. Vital EM, Dass S, Rawstron AC, Buch MH, Goeb V, Henshaw K, Ponchel F, Emery P: Management of nonresponse to rituximab in rheumatoid arthritis: predictors and outcome of retreatment. Arthritis Rheum 2010, 62:1273-1279.

40. Vital EM, Rawstron AC, Dass S, Henshaw K, Madden J, Emery P, McGonagle D: Reduced-dose rituximab in rheumatoid arthritis: efficacy depends on degree of B cell depletion. Arthritis Rheum 2011, 63:603-608.

41. Vital EM, Dass S, Buch MH, Henshaw K, Pease CT, Martin MF, Ponchel F, Rawstron AC, Emery P: B cell biomarkers of rituximab responses in systemic lupus erythematosus. Arthritis Rheum 2011, 63:3038-3047.

42. Tahir H, Rohrer J, Bhatia A, Wegener WA, Isenberg DA: Humanized anti-CD20 monoclonal antibody in the treatment of severe resistant systemic lupus erythematosus in a patient with antibodies against rituximab. Rheumatology 2005, 44:561-562.

43. Dass S, Rawstron AC, Vital EM, Henshaw K, McGonagle D, Emery P: Highly sensitive $B$ cell analysis predicts response to rituximab therapy in rheumatoid arthritis. Arthritis Rheum 2008, 58:2993-2999.

44. Mei HE, Frolich D, Giesecke C, Loddenkemper C, Reiter K, Schmidt S, Feist E, Daridon C, Tony HP, Radbruch A, Dorner T: Steady state generation of mucosal lg $\mathrm{A}^{+}$plasmablasts is not abrogated by $\mathrm{B}$ cell depletion therapy with rituximab. Blood 2010, 116:5181-5190.

45. Roll P, Dorner T, Tony H-P: Anti-CD20 therapy in patients with rheumatoid arthritis: predictors of response and $B$ cell subset regeneration after repeated treatment. Arthritis Rheum 2008, 58:1566-1575. 
46. Palanichamy A, Muhammad K, Roll P, Kleinert S, Dorner T, Tony HP: Rituximab therapy leads to reduced imprints of receptor revision in immunoglobulin $\mathrm{K}$ and $\lambda$ light chains. J Rheumato/ 2012, 39:1130-1138.

47. Boumans MJH, Thurlings RM, Gerlag DM, Vos K, Tak PP: Response to rituximab in patients with rheumatoid arthritis in different compartments of the immune system. Arthritis Rheum 2011, 63:3187-3194.

48. Alwayn IP, Xu Y, Basker M, Wu C, Buhler L, Lambrigts D, Treter S, Harper D, Kitamura H, Vitetta ES, Abraham S, Awwad M, White-Scharf ME, Sachs DH, Thall A, Cooper DK: Effects of specific anti-B and/or anti-plasma cell immunotherapy on antibody production in baboons: depletion of CD20and CD22-positive B cells does not result in significantly decreased production of anti-alphaGal antibody. Xenotransplantation 2001, 8:157-171.

49. Schroder C, Azimzadeh AM, Wu G, Price JO, Atkinson JB, Pierson RN: AntiCD20 treatment depletes B-cells in blood and lymphatic tissue of cynomolgus monkeys. Transpl Immunol 2003, 12:19-28.

50. Leandro MJ, Cooper N, Cambridge G, Ehrenstein MR, Edwards JC: Bone marrow B-lineage cells in patients with rheumatoid arthritis following rituximab therapy. Rheumatology 2007, 46:29-36.

51. Rehnberg M, Amu S, Tarkowski A, Bokarewa MI, Brisslert M: Short- and longterm effects of anti-CD20 treatment on B cell ontogeny in bone marrow of patients with rheumatoid arthritis. Arthritis Res Ther 2009, 11:R123.

52. Nakou M, Katsikas G, Sidiropoulos P, Bertsias G, Papadimitraki E, Raptopoulou A, Koutala H, Papadaki HA, Kritikos H, Boumpas DT: Rituximab therapy reduces activated $B$ cells in both the peripheral blood and bone marrow of patients with rheumatoid arthritis: depletion of memory B cells correlates with clinical response. Arthritis Res Ther 2009, 11: R131.

53. Cioc AM, Vanderwerf SM, Peterson BA, Robu VG, Forster CL, Pambuccian SE: Rituximab-induced changes in hematolymphoid tissues found at autopsy. Am J Clin Pathol 2008, 130:604-612.

54. Audia S, Samson M, Guy J, Janikashvili N, Fraszczak J, Trad M, Ciudad M, Leguy V, Berthier S, Petrella T, Aho-Glele S, Martin L, Maynadie M, Lorcerie B, Rat P, Cheynel N, Katsanis E, Larmonier N, Bonnotte B: Immunologic effects of rituximab on the human spleen in immune thrombocytopenia. Blood 2011, 118:4394-4400.

55. Kneitz C, Wilhelm M, Tony HP: Effective B cell depletion with rituximab in the treatment of autoimmune diseases. Immunobiology 2002, 206:519-527.

56. Mamani-Matsuda M, Cosma A, Weller S, Faili A, Staib C, Garcon L, Hermine O, Beyne-Rauzy O, Fieschi C, Pers JO, Arakelyan N, Varet B, Sauvanet A, Berger A Paye F, Andrieu JM, Michel M, Godeau B, Buffet P, Reynaud CA, Weill JC: The human spleen is a major reservoir for long-lived vaccinia virus-specific memory B cells. Blood 2008, 111:4653-4659.

57. Ramos EJ, Pollinger HS, Stegall MD, Gloor JM, Dogan A, Grande JP: The effect of desensitization protocols on human splenic B-cell populations in vivo. Am J Transplant 2007, 7:402-407.

58. Gelinck LBS, Teng YKO, Rimmelzwaan GF, van den Bemt BJF, Kroon FP, van Laar JM: Poor serological responses upon influenza vaccination in patients with rheumatoid arthritis treated with rituximab. Ann Rheum Dis 2007, 66:1402-1403.

59. Oren S, Mandelboim M, Braun-Moscovici Y, Paran D, Ablin J, Litinsky I, Comaneshter D, Levartovsky D, Mendelson E, Azar R, Wigler I, Balbir-Gurman A, Caspi D, Elkayam O: Vacciantion against influenza in patients with rheumatoid arthritis: the effect of rituximab on the humoral response. Ann Rheum Dis 2008, 67:937-941.

60. Van Assen S, Holvast A, Benne CA, Posthumus MD, van Leeuwen MA, Voskuyl AE, Blom M, Risselada AP, ce Haan A, Westra J, Kallenberg CGM, Bijl M: Humoral responses after influenza vaccination are severely reduced in patients with rheumatoid arthritis treated with rituximab. Arthritis Rheum 2010, 62:75-81.

61. Rehnberg M, Brisslert M, Amu S, Zendjanchi K, Hawi G, Bokarewa MI: Vaccination response to protein and carbohydrate antigens in patients with rheumatoid arthritis after rituximab treatment. Arthritis Res Ther 2010, 12:R111.

62. Arad U, Tzadok S, Amir S, Mandelboim M, Mendelson E, Wigler I, SarbagilMaman H, Paran D, Caspi D, Elkayam O: The cellular immune response to influenza vaccination is preserved in rheumatoid arthritis patients treated with rituximab. Vaccine 2011, 29:1643-1648.

63. Adler S, Krivine A, Weix J, Rozenberg F, Launay O, Huesler J, Guillevin L, Viliger PM: Protective effect of $\mathrm{A} / \mathrm{H} 1 \mathrm{~N} 1$ vaccination in immune-mediated disease - a prospectively controlled vaccination study. Rheumatology 2012 , 51:695-700.

64. Eisenberg R, Jawad AF, Boyer J, Maurer K, McDonald K, Prak ETL, Sullivan KE: Rituximab-treated patients have a poor response to influenza vaccination. J Clin Immunol 2013, 33:388-396.

65. Takata T, Suzumiya J, Ishikawa T, Takamatsu Y, Ikematsu H, Tamura K: Attenuated antibody reaction for the primary antigen but not for the recall antigen of influenza vaccination in patients with non-Hodgkin B-cell lymphoma after the administration of rituximab-CHOP. J Clin Exp Hematopathol 2009, 49:9-13.

66. Vos K, Thurlings RM, Wijbrandts CA, van Schaardenburg D, Gerlag DM, Tak PP: Early effects of rituximab on the synovial cell infiltrate in patients with rheumatoid arthritis. Arthritis Rheum 2007, 56:772-778.

67. Kavanaugh A, Rosengren S, Lee SJ, Hammaker D, Firenstein GS, Kalunian K, Wei N, Boyle DL: Assessment of rituximab's immunomodulatory synovial effects (ARISE trial). 1: clinical and synovial biomarker results. Ann Rheum Dis 2008, 67:402-408

68. Teng YK, Levarht EW, Hashemi M, Bajema IM, Toes RE, Huizinga TW, van Laar $\mathrm{JM}$ : Immunohistochemical analysis as a means to predict responsiveness to rituximab treatment. Arthritis Rheum 2007, 56:3909-3918.

69. Thurlings RM, Teng O, Vos K, Gerlag DM, Aarden L, Stapel SO, van Laar JM, Tak PP, Wolbinj GJ: Clinical response, pharmacokinetics, development of human anti-chimaeric antibodies, and synovial tissue response to rituximab treatment in patients with rheumatoid arthritis. Ann Rheum Dis 2010, 69:409-412.

70. Pijpe J, Meijer JM, Bootsma H, van der Wal JE, Spijkervet FK, Kallenberg CG, Vissink A, Ihrler S: Clinical and histological evidence of salivary gland restoration supports the efficacy of rituximab treatment in Sjogren's syndrome. Arthritis Rheum 2009, 60:3251-3256.

71. Pers JO, Devauchelle V, Daridon C, Bendaoud B, Le Berre R, Bordron A, Hutin P, Renaudineau Y, Dueymes M, Loisel S, Berthou C, Saraux A, Youinou P: BAffmodulated repopulation of $B$ lymphocytes in the blood and salivary glands of rituximab-treated patients with Sjogren's syndrome. Arthritis Rheum 2007, 56:1464-1477.

72. Thaunat O, Patey N, Gautreau C, Lechaton S, Fremeaux-Bacchi V, DieuNosjean MC, Cassuto-Viguier E, Legendre C, Delahousse M, Lang P, Michel JB, Nicoletti A: B cell survival in intragraft tertiary lymphoid organs after rituximab therapy. Transplantation 2008, 85:1648-1653.

doi:10.1186/ar3908

Cite this article as: Leandro MJ: B-cell subpopulations in humans and their differential susceptibility to depletion with anti-CD20 monoclonal antibodies. Arthritis Research \& Therapy 2013, 15(Suppl 1):S3. 